Research Paper

\title{
The Value of NT-proBNP the Follow - up of Children with Dilated Cardiomyopathy
}

\author{
Dang Thi Hai Van ${ }^{1, *}$, Dang Phuong Thuy ${ }^{2}$, Nguyen Thi Hai $\mathrm{Ha}^{2}$ \\ ${ }^{1}$ Hanoi Medical Univercity, No.1 Ton That Tung, Kim Lien, Dong Da, Hanoi, Vietnam \\ ${ }^{2}$ Vietnam National Children's Hospital, 18/879 La Thanh, Dong Da, Hanoi, Vietnam
}

Received 19 December 2020

Revised 18 March 2020; Accepted 20 April 2020

\begin{abstract}
Objectives: To survery the plasma NT-proBNP concentration, the correlation between NT-proBNP concentration and the New York Pediatric Heart Failure Index (NYU PHFI) in children with dilated cardiomyopathy. Comment on the association of NT-proBNP with the level of left ventricular dilatation and systolic function in the follow - up of children with dilated cardiomyopathy.
\end{abstract}

Method: Prospective, descriptive study.

Results: At the time of diagnosis, 32 out of 33 patients (97\%) had an NTproBNP level higher than $97,5^{\text {th }}$ percentile. The log NT-proBNP was significantly positively correlated with PHFI $(\mathrm{r}=0.84 ; \mathrm{P}<0.001)$. The $\log \mathrm{NT}$-proBNP wasalso positively correlated with LVED ( $r=0.519 ; p<0.001)$, was negatively correlated with LVEF $(r=-0.736 ; p<0.001)$ and LVFS $(\mathrm{r}=-0.737 ; \mathrm{p}<0.001$. The initial levels of serum NT-proBNP were not different from three progressed groups. However, at 3 months after diagnosis, the NT-proBNP of the improved group was significantly different from each other.

Conclusion: NT-proBNP is an excellentbiomarker used to diagnose and assess cardiac insufficiency inthe follow - up of children with dilated cardiomyopathy.

Keywords: NT-proBNP, dilated cardiomyopathy.

* Corresponding author.

E-mail address: dthv2004@ hotmail.com

https://doi.org/10.25073/ jprp.v4i2.196 


\title{
Nghiên cứu giá trị của nồng độ NT-proBNP trong theo dõi bệnh cơ tim giãn ở trẻ em
}

\author{
Đặng Thị Hải Vân ${ }^{1, *}$, Đặng Phương Thúy ${ }^{2}$, Nguyễn Thị Hải Hà2 \\ ${ }^{I}$ Đại học Y Hà Nội, Số 1 Tôn Thất Tùng, Đống Đa, Hà Nội, Việt Nam \\ ${ }^{2}$ Bệnh viện Nhi Trung ương, 18/879 La Thành, Đống Đa, Hà Nội, Việt Nam
}

Nhận ngày 19 tháng 02 năm 2019

Chỉnh sửa ngày 17 tháng 3 năm 2020; Chấp nhận đăng ngày 20 tháng 3 năm 2020

\section{Tóm tắt}

Mục tiêu: Khảo sát nồng độ NT-proBNP huyết tương, mối tương quan giữa nồng độ NT-proBNP với mức độ suy tim theo thang điểm PHFI và nhận xét mối liên quan của NTproBNP với mức độ giãn và chức năng tâm thu thất trái trên siêu âm tim trong theo dõi bệnh cơ tim giãn ở trẻ em.

Phương pháp: mô tả tiến cứu.

Kết quả:32/33 bệnh nhân (97\%) có nồng độ NT-proBNP cao hơn giá trị bách phân vị thứ 97,5 theo tuổi. Giá trị log NT-proBNP có mối tương quan thuận chặt chẽ với mức độ suy tim trên lâm sàng theo thang điểm PHFI $(\mathrm{r}=0,84 ; \mathrm{p}<0,001)$, tương quan thuận với đường kính thất trái cuối tâm trương $(\mathrm{r}=0,519 ; \mathrm{p}<0,001)$, tương quan nghịch với phân suất tống máu thất trái $(\mathrm{r}=-0,736 ; \mathrm{p}<0,001)$ và phân suất co ngắn sợi $\mathrm{cơ}(\mathrm{r}=-0,737$; $\mathrm{p}<0,001)$. Tại thời điểm chẩn đoán, nồng độ NT-proBNP của 3 nhóm tiến triển trong nghiên cứu không có sự khác biệt. Tuy nhiên sau 3 tháng chẩn đoán, nhóm tiến triển tốt cải thiện rõ rệt, khác biệt có ý nghĩa so với nhóm tử vong/ghép tim và nhóm tiến triển xấu.

Kết luận: NT-proBNP là một dấu ấn sinh học nên được sử dụng trong chẩn đoán và đánh giá mức độ suy tim khi theo dõi bệnh cơ tim giãn ở trẻ em.

Tù khóa: NT-proBNP, bệnh cơ tim giãn.

\section{1. Đặt vấn đề}

Bệnh cơ tim giãn là thể thường gặp nhất trong các bệnh cơ tim tiên phát ở trẻ em. Bệnh có tiến triển tương đối nặng nề, tiên lượng dè dặt nên cần những nồ lực lớn hơn đề chẩn đoán sớm và tối ưu hóa các chiến lược phân tầng nguy cơ. Một số nghiên cứu trên thế giới đã chứng minh nồng độ $\mathrm{N}$ Terminal pro-Brain Natriuretic Peptide (NT-proBNP) huyết tương tăng trong bệnh

"Tác giả liên hệ.

Địa chi email: dthv2004@hotmail.com

https://doi.org/10.25073/ jprp.v4i2.196 cơ tim giãn là yếu tố có giá trị tiên lượng tỷ lệ tử vong, khả năng nhập viện và khả năng phải ghép tim ở người lớn. Tuy nhiên, các nghiên cứu trên trẻ em còn hạn chế. Vì vậy, chúng tôi chúng tôi tiến hành nghiên cứu đề tài với 2 mục tiêu:

1. Khảo sát nồng độ NT-proBNP huyết tuoong và mối tương quan giữa nồng độ NT-proBNP huyết tuoong với múc độ suy tim theo thang điểm PHFI trong bệnh co tim giãn ở tré em.

2. Nhận xét mối liên quan cua NT-proBNP huyết tương với mức độ giãn và chưc năng tâm thu thất trái trên siêu âm tim trong theo dõi bệnh co tim giãn ở trẻ em. 


\section{2. Đối tượng và phương pháp nghiên cứu}

2.1. Đối tương, thời gian và địa điểm nghiên cứu

Tất cả bệnh nhi bệnh cơ tim giãn được chẩn đoán, điều trị tại Bệnh viện Nhi Trung ương từ $01 / 12 / 2015$ đến 30/9/2017.

2.1.1. Tiêu chuẩn xác định bệnh cơ tim giãn [1]:

- Tiêu chuẩn chẩn đoán dựa trên siêu âm tim:

+ Thất trái giãn hình cầu, đường kính thất trái cuối tâm trương lớn hơn +2SD so với trẻ bình thường có cùng diện tích da.

Sơ đồ nghiên cứu
+ Chức năng tâm thu thất trái giảm: phân suất tống máu $(\mathrm{EF})<50 \%$ hoặc phân suất co ngắn sợi cơ $(\mathrm{FS})<28 \%$.

+ Không có dị tật tim bẩm sinh, không có bất thường mạch máu phối hợp.

- Loại trừ các trường hợp cơ tim giãn thứ phát do các bệnh lí khác như tim bẩm sinh (bất thường xuất phát động mạch vành, hẹp eo động mạch chủ nặng...), rối loạn nhịp tiên phát, tăng huyết áp, bệnh Kawasaki, tổn thương thiếu máu cục bộ do ngạt sơ sinh hoặc sau hồi sức tim phổi.

\subsection{Phưong pháp nghiên cứu}

Đề tài được thực hiện theo phương pháp mô tả tiến cứu.

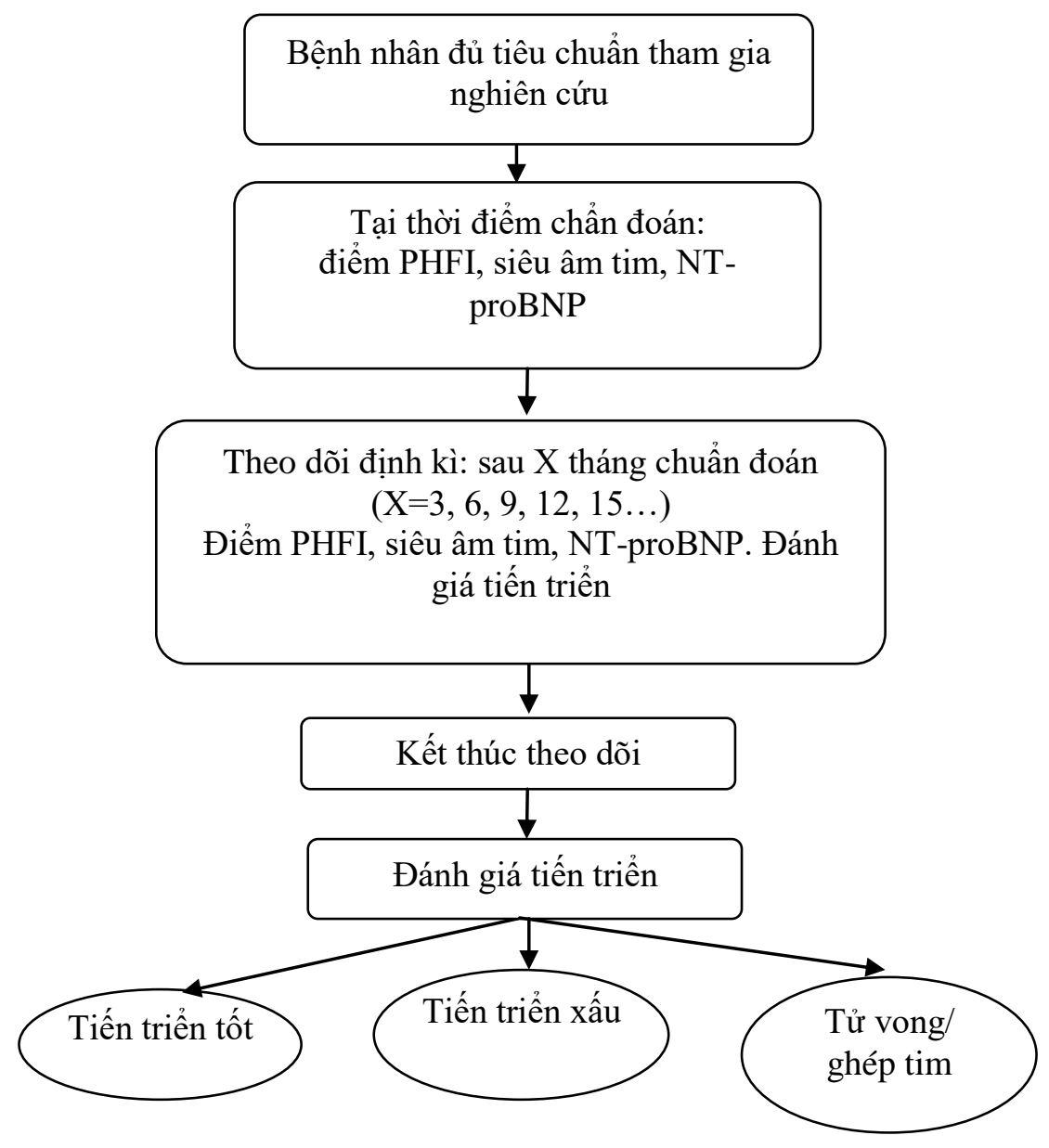


Trong đó:

- Tiến triển tốt: Khi đáp ứng đủ 2 tiêu chuẩn như mức độ suy tim (theo điểm PHFI) giảm và chỉ số trên siêu âm tim cải thiện (EF và $F S$ tăng, $D d$ giảm).

- Xấu: Khi không đáp ứng đủ cả 2 tiêu chuẩn trên.

\subsection{Xử lý và phân tích số liệu}

Sử dụng các thuật toán thống kê y học bằng phần mềm SPSS 16.0.

\section{Kết quả nghiên cứu}

Qua nghiên cứu 33 trường hợp bệnh cơ tim giãn được chẩn đoán, điều trị tại Bệnh viện Nhi Trung ương trong thời gian từ 01/12/2015 đến 30/9/2017, thu được một số kết quả sau:

\subsection{Nồng độ NT-proBNP và mối tương} quan với múc độ suy tim theo thang điểm PHFI (Hình 1)

Khi vẽ biểu đồ phân bố và thực hiện kiểm định Shapiro-wilk chúng tôi thấy nồng độ NT-proBNP của đối tượng nghiên cứu tại thời điểm chẩn đoán không chuẩn $(\mathrm{p}<$ $0,05)$ với giá trị trung vị là $12348,1 \mathrm{pg} / \mathrm{ml}$ (IQR: 4938,8 pg/ml - 27412,4 pg/ml). Do đó, chúng tôi dùng phép biến đổi logarit cơ số 10 để thu được biến log NT-proBNP có phân bố chuẩn với $\mathrm{X} \pm \mathrm{SD}=4,013 \pm 0,621$ (Hình 2, Hình 3).

3.2. NT-proBNP và các chỉ số siêu âm tim trong theo dõi bệnh co tim giãn

Khi kết thúc nghiên cứu, 33 bệnh nhân bệnh cơ tim giãn chia làm 3 nhóm tiến triển: 16 bệnh nhân tử vong hoặc ghép tim (1 bệnh nhân ghép tim), 14 bệnh nhân tiến triền tốt, 3 bệnh nhân tiến triển xấu (Hình 4 , Hình 5 , Hình 6).

\section{Bàn luận}

4.1 Nồng độ NT-proBNP và mối tuoong quan với múcc độ suy tim theo điểm PHFI

Tại thời điểm chẩn đoán, tất cả bệnh nhân trong nghiên cứu của chúng tôi có nồng độ NT-proBNP trên bách phân vị thứ 95 theo tuổi.

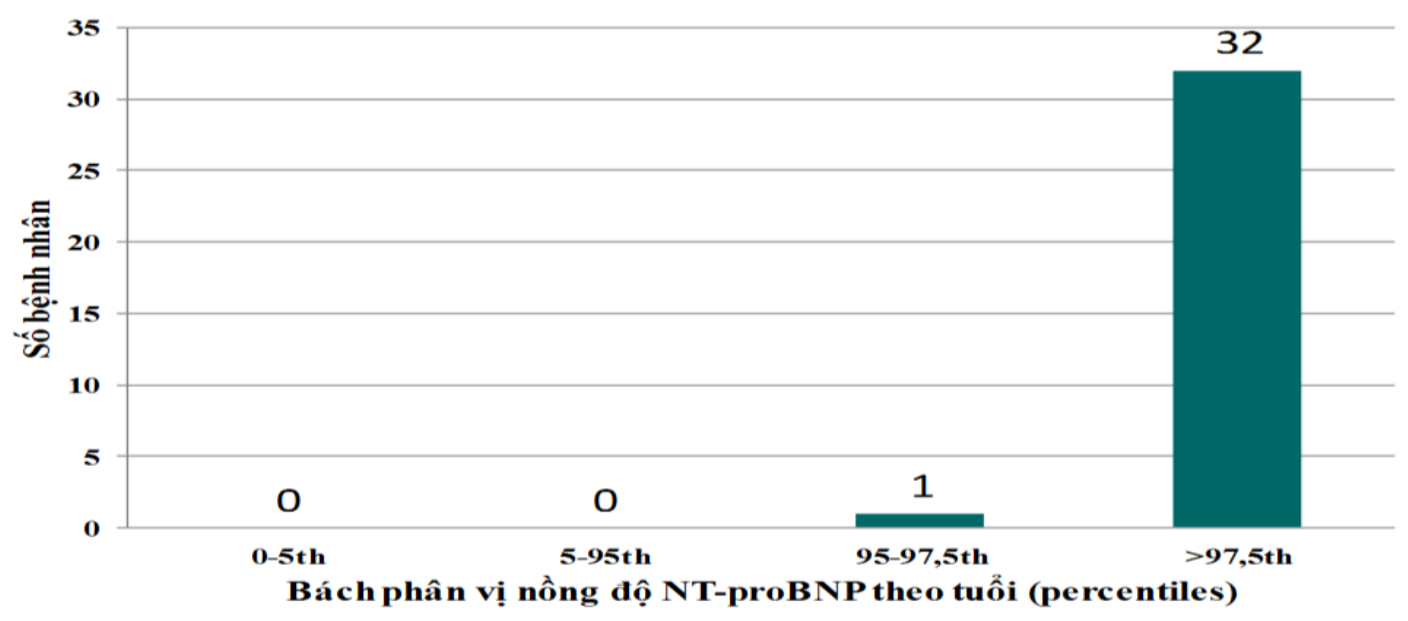

Hình 1. Nồng độ NT-proBNP so với giới hạn bình thường theo tuổi. Nhận xét: Tại thời điểm chẩn đoán, có 32/33 (97\%) bệnh nhân có nồng độ NT-proBNP trên bách phân vị thứ 97,5 theo tuổi. 

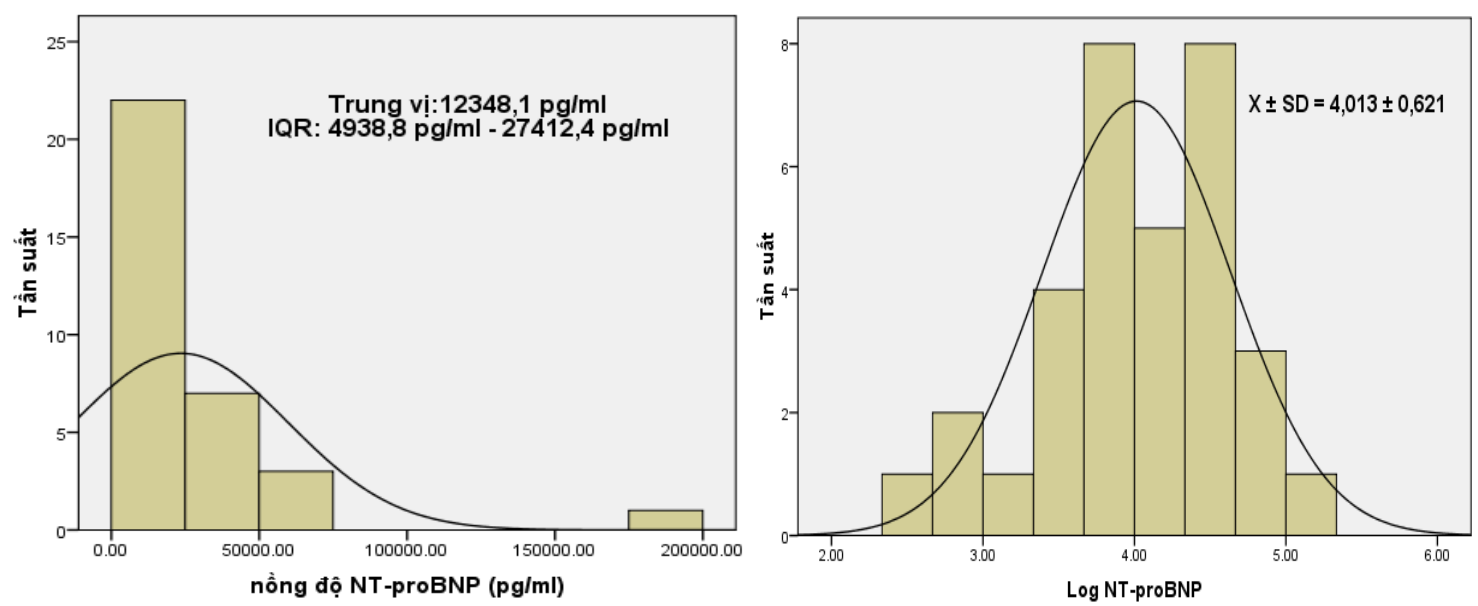

Hình 2. Phân bố nồng độ NT-proBNP và $\log$ NT-proBNP tại thời điểm chẩn đoán.

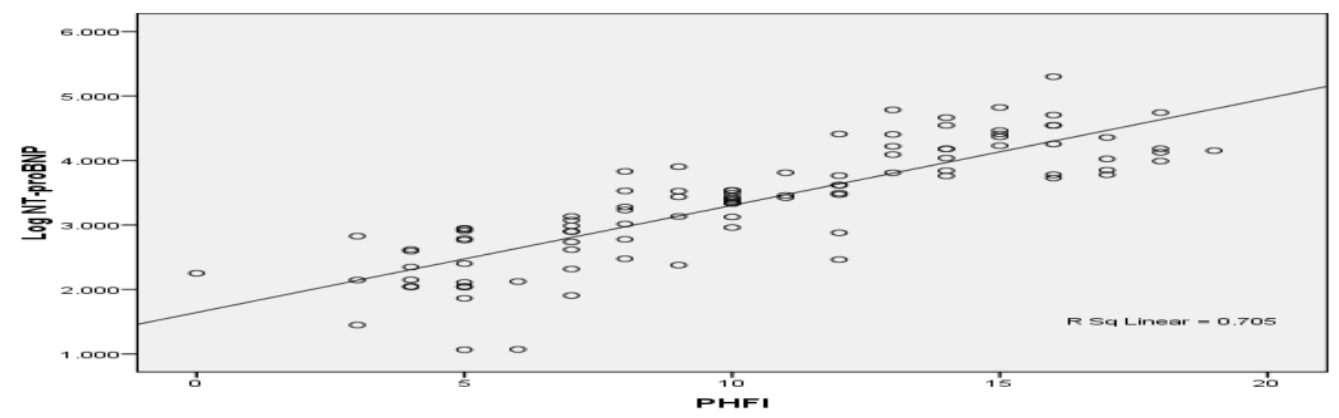

Hình 3. Mối tương quan giữa log NT-proBNP và mức độ suy tim theo thang điểm PHFI. Nhận xét: Ở bệnh nhân bệnh cơ tim giãn có sự tương quan thuận giữa $\log \mathrm{NT}$-proBNP và mức độ suy tim theo điểm PHFI $(\mathrm{p}<0,001 ; \mathrm{r}=0,840 ; \mathrm{Y}=0,166 \mathrm{X}+1,643)$.

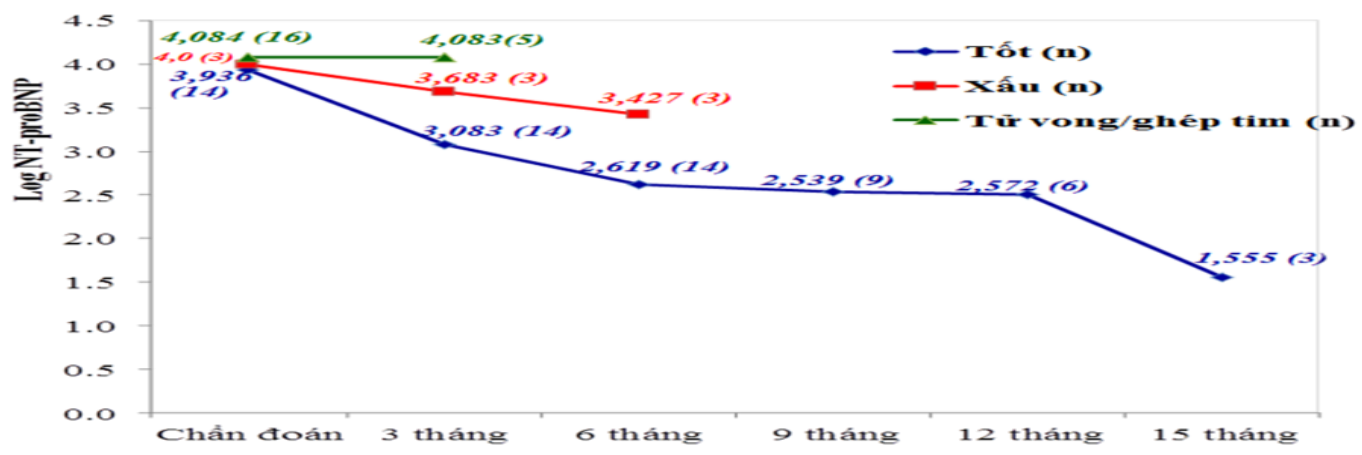

Hình 4. Diễn biến giá trị log NT-proBNP của 3 nhóm tiến triển

(n là số bệnh nhân của mồi nhóm có số liệu tại thời điểm đánh giá)

Nhận xét: Tại thời điểm chẩn đoán, giá trị log NT-proBNP của 3 nhóm tiến triển không có sự khác biệt có ý nghĩa thống kê. Tuy nhiên, nhóm tiến triển tốt cải thiện rõ rệt ngay từ sau khi điều trị, khác biệt có ý nghĩa so với 2 nhóm còn lại từ thời điểm 3 tháng sau chẩn đoán $(\mathrm{p}<0,05)$.

Nhóm tử vong cải thiện rất ít và gần như không thay đổi. 


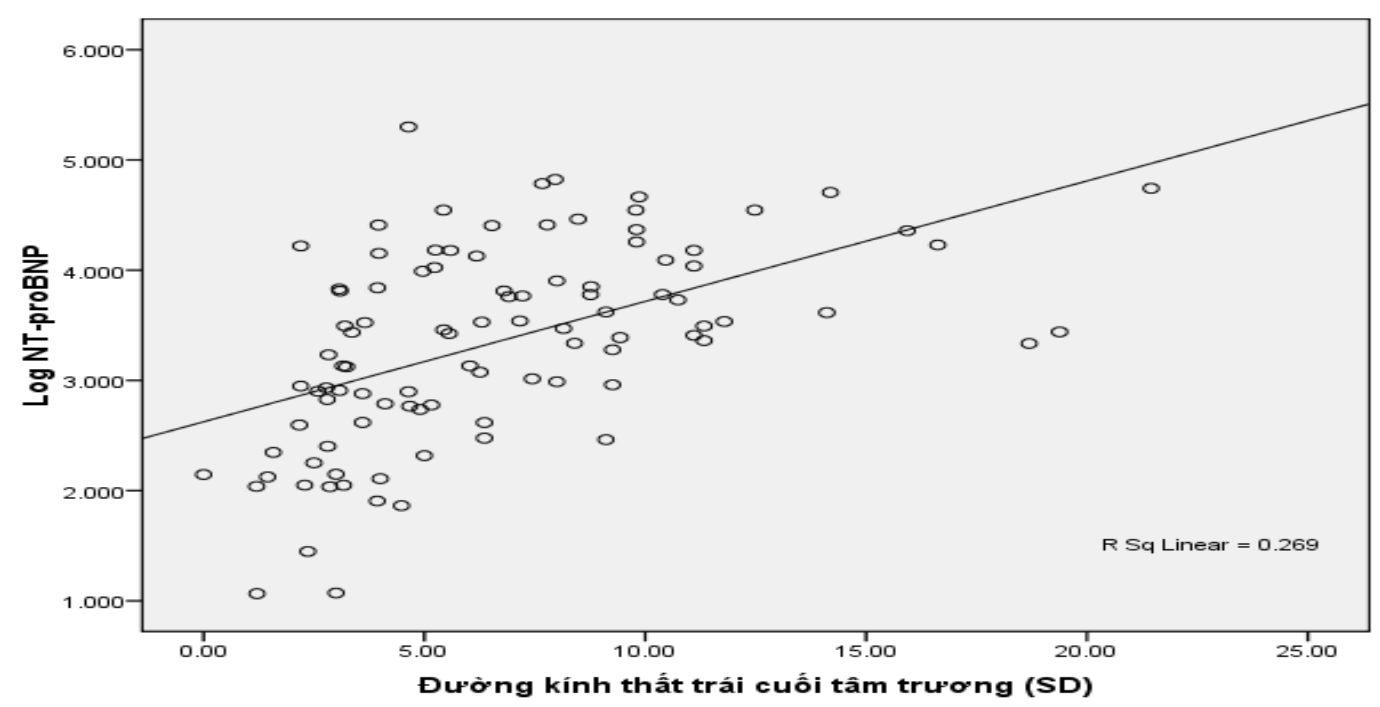

Hình 5. Mối liên quan giữa log NT-proBNP và đường kính thất trái cuối tâm trương. Nhận xét: Có sự tương quan thuận giữa $\log \mathrm{NT}-$ proBNP và đường kính thất trái cuối tâm trương $(\mathrm{p}<0,001 ; \mathrm{r}=0,519 ; \mathrm{Y}=0,109 \mathrm{X}+2,624)$.
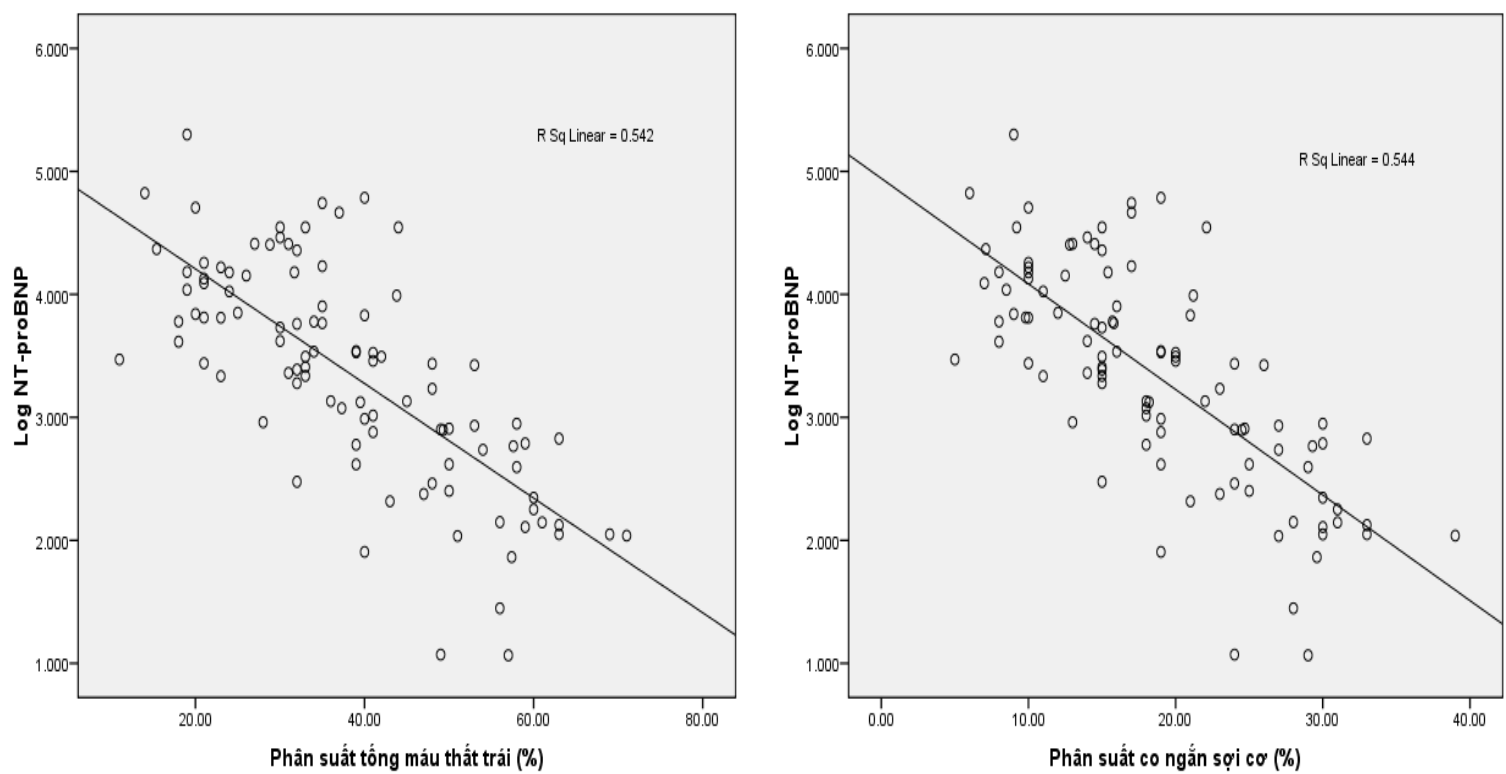

Hình 6. Mối liên quan giữa log NT-proBNP và chức năng tâm thu thất trái.

Nhận xét: Có sự tương quan nghịch giữa $\log \mathrm{NT}$-proBNP và phân suất tống máu thất trái $(\mathrm{p}<0,001 ; \mathrm{r}=-0,736 ; \mathrm{Y}=5,139-0,047 \mathrm{X})$, và phân suất co ngắn sợi cơ $(\mathrm{p}<0,001 ; \mathrm{r}=-0,737 ; \mathrm{Y}=4,943-0,086 \mathrm{X})$.

Nồng độ NT-proBNP của đối tượng nghiên cứu tại thời điểm chẩn đoán phân bố không chuẩn nên chúng tôi dùng phép biến đổi logarit cơ số 10 để thu được biến $\log$ $\mathrm{NT}$-proBNP có phân bố chuẩn với $\mathrm{X} \pm \mathrm{SD}$ $=4,013 \pm 0,621$. Kết quả nghiên cứu của 
chúng tôi tương tự với kết quả của Narin và cộng sự [2]. Hơn nữa, trong nghiên cứu của Narin còn cho thấy ngay cả ở những bệnh nhân có triệu chứng, hay không có triệu chứng sau khi điều trị, nồng độ NT-proBNP huyết thanh vẫn cao hơn nhóm chứng. Xét nghiệm NT-proBNP có thể được dùng để phân biệt trẻ khỏe mạnh với những bệnh nhân không có dấu hiệu lâm sàng và triệu chứng suy tim sau khi điều trị nhưng vẫn có rối loạn chức năng tâm thu thất trái trên siêu âm tim với điểm cắt là 174,3 pg/ml [2].

Triệu chứng lâm sàng của bệnh cơ tim giãn ở trẻ em không đặc hiệu. Suy tim là biểu hiện chủ yếu và cũng là nguyên nhân tử vong hàng đầu của bệnh nhưng thường tiến triển thầm lặng và không có xét nghiệm đơn lẻ, đặc hiệu để chẩn đoán. Việc chẩn đoán sớm và chính xác mức độ nặng của suy tim rất cần thiết để phân tầng nguy cơ trong điều trị, quản lý và tiên lượng bệnh. Nghiên cứu của chúng tôi đánh giá mức độ suy tim trên lâm sàng của đối tượng nghiên cứu theo thang điểm PHFI. Đây là một chỉ số có thể áp dụng cho trẻ em ở mọi lứa tuổi. Bên cạnh đó, nó còn giúp đánh giá một cách toàn diện (lâm sàng, xét nghiệm, điều trị) và chính xác mức độ nặng cũng như hiệu quả điều trị suy tim ở trẻ em. Kết quả nghiên cứu của chúng tôi cho thấy có mối tương quan thuận rất chặt chẽ giữa điểm $\mathrm{PHFI}$ và giá trị $\log \mathrm{NT}$-proBNP $(\mathrm{r}=0,84 ; \mathrm{p}<0,001)$. Kết quả nghiên cứu của Nasser và cộng sự cũng cho thấy mối tương quan này ở trẻ bị bệnh cơ tim giãn với $\mathrm{r}=0,81 ; \mathrm{p}=0,01$ [3]. Có thể thấy việc chẩn đoán và đánh giá mức độ nặng của suy tim luôn là một thách thức trong thực hành lâm sàng nhi khoa đặc biệt là đối với trẻ sơ sinh và trẻ nhỏ. Do khó khăn trong việc đánh giá khách quan về mức độ khó thở, mệt mỏi và đau ngực, đó lại là các yếu tố cơ sở của phân độ NYHA và Ross. Đối với thang điểm PHFI, tuy đây là một chỉ số mang tính khách quan và chính xác hơn các phân loại ra đời trước nó, nhưng lại phức tạp và khó đánh giá hơn, đặc biệt khó áp dụng trong các trường hợp cấp cứu. Khi đó, NT-proBNP có thể là một dấu ấn sinh học hữu ích, khách quan, dễ் thực hiện, nhanh có kết quả và có thể tiến hành ở hầu hết các phòng thí nghiệm. Nó cho phép đánh giá thường xuyên, giúp chẩn đoán sớm, chính xác mức độ nặng của suy tim ở bệnh nhân bệnh cơ tim giãn.

4.2 Mối liên quan của NT-proBNP với múc độ giãn và chức năng tâm thu thất trái trên siêu âm tim trong theo dõi bệnh co tim giãn.

Tại thời điểm kết thúc nghiên cứu, trong số 33 bệnh nhân của chúng tôi chỉ có 14 bệnh nhân $(42,4 \%)$ có tiến triển lâm sàng và siêu âm tim đều cải thiện tốt, 3 bệnh nhân (9,1\%) không cải thiện, 16 bệnh nhân (48,5\%) tử vong hoặc ghép tim. Những trường hợp tử vong hoặc cần đến ghép tim đều xảy ra trong vòng 6 tháng đầu sau chẩn đoán. Tỷ lệ sống sau 6 tháng chỉ đạt 51,5\%.

Việc định lượng nồng độ NT-proBNP lúc chẩn đoán là cần thiết để chẩn đoán xác định và đánh giá mức độ nặng của suy tim. Tuy nhiên, với duy nhất kết quả nồng độ NT-proBNP ban đầu không thể phản ánh toàn bộ triến triển trên lâm sàng và kết quả điều trị ở bệnh nhân suy tim nói chung. Nhiều nghiên cứu trước đây cho thấy cùng với siêu âm tim, việc theo dõi diễn biến nồng độ NT-proBNP có ý nghĩa rất quan trọng trong việc đánh giá đáp ứng điều trị và tiên lượng tử vong cũng như tái nhập viện ở bệnh nhân suy tim. Dựa trên cơ sở này, chúng tôi tiến hành kiểm tra nồng độ NT-proBNP của đối tượng nghiên cứu tại nhiều thời điểm: lúc chẩn đoán, 3 tháng, 6 tháng sau chẩn đoán và cứ 3 tháng sau đó cho đến khi kết thúc theo dõi. Kết quả thu được cho thấy tại thời điểm chẩn đoán, giá trị $\log$ NT-proBNP của các nhóm tiến triển 
không có sự khác biệt. Tuy nhiên, đến thời điểm sau 3 tháng, nhóm tiến triển tốt có giá trị log NT-proBNP thấp hơn so với 2 nhóm còn lại và sự khác biệt có ý nghĩa thống kê. Đặc biệt, ở nhóm tiến triển tốt có sự cải thiện rõ rệt $(3,936 \pm 0,557$ so với $3,083 \pm$ $0,529, \mathrm{p}<0,05)$. Trái lại, ở các nhóm tiến triển không tốt có giá trị log NT-proBNP sau 3 tháng gần như không thay đồi. Như vậy, theo dõi nồng độ NT-proBNP và sự thay đổi của nó trong 3 tháng đầu sau chẩn đoán phần nào có thể đánh giá được tiến triển của bệnh. Nhưng nồng độ NT-proBNP thay đổi bao nhiêu so với trị số ban đầu thì chúng tôi vẫn chưa có con số cụ thể do hạn chế cỡ mẫu của nghiên cứu làm ảnh hưởng đến độ mạnh của kiểm định thống kê. Do vậy, rất cần có những nghiên cứu với số lượng bệnh nhân lớn hơn để làm sáng tỏ vấn đề này.

Kết quả nghiên cứu của chúng tôi phù hợp với báo cáo của Kim và cộng sự năm 2013 [4]. Báo cáo này còn cho thấy giá trị log NT-proBNP tại thời điểm 3 tháng sau chẩn đoán cứ tăng 1 đơn vị (tức là nồng độ NT-proBNP tăng gấp 10 lần) thì bệnh nhân có nguy cơ tử vong hoặc ghép tim tăng gấp 2,078 lần. Và để dự báo các biến cố tim mạch có thể xảy ra, giá trị điểm cắt của nồng độ NT-proBNP huyết thanh tại thời điểm 3 tháng sau chẩn đoán là $681 \mathrm{pg} / \mathrm{ml}$ với độ nhạy $100 \%$; độ đặc hiệu 59,6\%; diện tích dưới đường cong ROC là 0,846 . Tác giả cũng cho rằng nồng độ $\mathrm{NT}$-proBNP huyết thanh ban đầu không có ý nghĩa tiên lượng vì nó bị ảnh hưởng bởi nhiều yếu tố như mức độ hoạt động của bệnh, nguyên nhân gây bệnh và thời gian khởi phát bệnh [4]. Có một số báo cáo lại chỉ ra rằng xét nghiệm NT-proBNP và theo dõi sự thay đổi của nồng độ NT-proBNP ở một số thời điểm khác với nghiên cứu của chúng tôi trong quá trình theo dõi có giá trị dự báo các biến cố tim mạch ở bệnh nhân bệnh cơ tim giãn. Susanna và cộng sự khi tiến hành theo dõi trên 115 bệnh nhân bệnh cơ tim giãn trong 7 năm (từ năm 2006 đến 2013) với thời gian theo dõi trung bình là 4,8 năm cho thấy giá trị nồng độ NT-proBNP tại thời điểm chẩn đoán cũng không có giá trị tiên lượng tử vong. Những nếu nồng độ NT-proBNP sau một năm chẩn đoán cao gấp đôi ban đầu thì sẽ tăng nguy cơ tử vong lên 2,9 lần [5]. Những khác biệt về kết quả giữa nghiên cứu của chúng tôi với các nghiên cứu khác trên trẻ em có thể do thời gian tiến hành, thời gian theo dõi trong nghiên cứu của chúng tôi ngắn, số lượng bệnh nhân ít mà tỷ lệ tử vong cao và nhiều bệnh nhân tử vong ngay trong đợt đầu điều trị.

Đặc biệt, khi phân tích mối tương quan giữa giá trị log NT-proBNP với mức độ giãn và chức năng tâm thu thất trái trên siêu âm trong quá trình theo dõi, chúng tôi nhận thấy có mối tương quan chặt chẽ: Giá trị $\log$ NT-proBNP tỷ lệ thuận với đường kính thất trái cuối tâm trương $(\mathrm{r}=0,519$; $\mathrm{p}<0,001)$, tỷ lệ nghịch với phân suất tống máu thất trái $(\mathrm{r}=-0,736 ; \mathrm{p}<0,001)$, và phân suất co ngắn sợi cơ $(\mathrm{r}=-0,737$; $\mathrm{p}<0,001$ ). Điều này có nghĩa là nồng độ NT-proBNP ở bệnh nhân càng tăng, đồng thời thất trái càng giãn và chức năng tâm thu thất trái càng giảm. Tương tự với nghiên cứu của chúng tôi, các nghiên cứu trước đây cũng cho thấy mối tương quan này và khẳng định NT-proBNP có giá trị đánh giá chức năng tim trong quá trình theo dõi tiến triển bệnh. Trong một nghiên cứu khác ở những trẻ có tiền sử viêm cơ tim và bị bệnh cơ tim giãn cũng cho thấy log NT-proBNP tương quan nghịch với phân suất co ngắn sợi cơ $(r=-0,57 ; p=0,004)$, tương quan thuận với đường kính thất trái cuối tâm trương $(r=0,58 ; p=0,004)$. Ngoài ra nó còn có giá trị chẩn đoán và tiên lượng những trường hợp có tình trạng rối loạn chức năng 
thất trái kéo dài trên siêu âm tim [3]. Nghiên cứu của Zoair cũng chứng minh có sự tương quan nghịch giữa nồng độ NT-proBNP huyết tương với các thông số đánh giá chức năng tâm thu thất trái trên siêu âm tim như $\mathrm{EF}$ và FS, tương quan thuận với đường kính thất trái cuối tâm trương, và mối tương quan này ở nhóm bệnh đặc hiệu hơn so với nhóm chứng [6]. Đánh giá ý nghĩa của xét nghiệm NT-proBNP và siêu âm tim trong theo dõi và tiên lượng bệnh cơ tim giãn, một số nghiên cứu cho rằng xét nghiệm NT-proBNP có giá trị hơn là siêu âm tim. Năm 2013, nghiên cứu của Kim và cộng sự trên 68 trẻ bị bệnh cơ tim giãn tại Hàn Quốc cho thấy khi đưa vào phân tích đa biến thấy nồng độ NT-proBNP tại thời điểm sau 3 tháng, 6 tháng và mức độ thay đổi NT-proBNP sau 6 tháng điều trị có giá trị dự báo nguy cơ tử vong còn các chỉ số trên siêu âm tim lại không có ý nghĩa [4]. Nghiên cứu của Medar và cộng sự cũng cho thâyy sự thay đổi về nồng độ NT-proBNP trong quá trình điều trị liên quan đến các biến cố tim mạch có thể xảy ra trong một năm sau đó $(\mathrm{r}=0,616 ; \mathrm{p}=0,01)$ mạnh hơn là sự thay đồi về chỉ số $\mathrm{EF}$ trên siêu âm tim $(\mathrm{r}=-0,42 ; \mathrm{p}=0,15)$ [7]. Tác giả này nhấn mạnh rằng NT-proBNP có thể được sử dụng như là chỉ số độc lập, khách quan trong việc đánh giá đáp ứng điều trị hơn là siêu âm tim. Do xét nghiệm chính xác, nhanh có kết quả, có thể thực hiện ở hầu hết các phòng xét nghiệm. Trong khi để đánh giá trên siêu âm tim cần phải có bác sĩ chuyên khoa tim mạch, tốn nhiều thời gian, đòi hỏi phải an thần ở trẻ và mang tính chủ quan của người làm siêu âm tim.

\section{Kết luận}

Qua nghiên cứu nồng độ NT-proBNP ở 33 trẻ bị bệnh cơ tim giãn tại Bệnh viện Nhi
Trung ương từ tháng 12 năm 2015 đến tháng 9 năm 2017 chúng tôi rút ra một số kết luận:

5.1. Nồng độ NT-proBNP và mối tuoong quan với mức độ suy tim theo thang điểm PHFI trong bệnh co tim giãn ở trẻ em

- Tại thời điểm chẩn đoán, 32/33 bệnh nhân $(97 \%)$ có nồng độ NT-proBNP cao hơn giá trị bách phân vị thứ 97,5 theo tuổi. Phân bố nồng độ NT-proBNP của đối tượng nghiên cứu có giá trị trung vị là 12348,1 pg/ml; bách phân vị thứ 25 và 75 là: 4938,8 $\mathrm{pg} / \mathrm{ml}$ và $27412,4 \mathrm{pg} / \mathrm{ml}$.

- NT-proBNP có mối tương quan thuận chặt chẽ với mức độ suy tim trên lâm sàng theo thang điểm PHFI $(\mathrm{r}=0,84 ; \mathrm{p}<0,001)$.

5.2. Mối liên quan của NT-proBNP với múc độ giãn và chức năng tâm thu thất trái trên siêu âm tim trong theo dõi bệnh cơ tim giãn ơ trẻ em

- Tại thời điểm chẩn đoán, nồng độ NT-proBNP của 3 nhóm tiến triển trong nghiên cứu không có sự khác biệt. Tuy nhiên sau 3 tháng chẩn đoán, nhóm tiến triển tốt cải thiện rõ rệt, khác biệt có ý nghĩa so với nhóm tử vong/ghép tim và nhóm tiến triển xấu $(\mathrm{p}<0,05)$.

- Giá trị log NT-proBNP có mối tương quan thuận với đường kính thất trái cuối tâm trương ( $\mathrm{r}=0,519 ; \mathrm{p}<0,001)$, tương quan nghịch với phân suất tống máu thất trái $(\mathrm{r}=-0,736 ; \mathrm{p}<0,001)$ và phân suất co ngắn sợi cơ $(\mathrm{r}=-0,737 ; \mathrm{p}<0,001)$.

\section{Tài liệu tham khảo}

[1] Molina K.M, Shrader P, Colan S. D et al. Predictors of disease progression in pediatric dilated cardiomyopathy. Circ Heart Fail 2013; 6(6): 1214-1222. 
[2] Narin N, Hekimoglu B, Baykan A et al. The role of $\mathrm{N}$-terminal proBNP in the clinic scoring of heart failure due to dilated cardiomyopathy in children. Clin Lab 2014 ; 60(4):563-570.

[3] Nasser N, Perles Z, Rein A.J et al. NTproBNP as a marker for persistent cardiac disease in children with history of dilated cardiomyopathy and myocarditis. Pediatr Cardio 2006;27(1):87-90.

[4] Kim G, Lee O.J, Kang I.S et al. Clinical implications of serial serum N-terminal prohormone brain natriuretic peptide levels in the prediction of outcome in children with dilated cardiomyopathy. Am J Cardiol 2013; 112(9):1455-1460.

[5] Susanna B.S, Rizopoulos D, Marchie S.G et al. Usefulness of Serial N-terminal Pro-B- type Natriuretic Peptide Measurements to Predict Cardiac Death in Acute and Chronic Dilated Cardiomyopathy in Children. Am J Cardiol 2016;118(11):1723-1729.

[6] Zoair A, Mawlana W, El-Bendary A et al. Serum levels of amino terminal of probrain natriuretic peptide (NT-Pro BNP) as a diagnostic and prognostic biomarker in children with dilated cardiomyopathy. Tanta Medical Journal 2014; 42(2):53-57.

[7] Medar S, Hsu D.T, Ushay H.M et al. Serial measurement of NT-proBNP predicts adverse cardiovascular outcome in children with primary myocardial dysfunction and acute decompensated heart failure (ADHF). Pediatr Crit Care Med 2015;16(6):529-534. 